\title{
Functional outcomes and complications of intramedullary fixation devices for Midshaft clavicle fractures: a systematic review and meta-analysis
}

Paul Hoogervorst ${ }^{1,2^{*}}$, Tess van Dam ${ }^{3}$, Nico Verdonschot ${ }^{1,4}$ and Gerjon Hannink ${ }^{5}$

\begin{abstract}
Background: An alternative to the current gold standard in operative treatment of displaced midshaft clavicle fractures (DMCF) using plate osteosynthesis, is internal fixation by means of intramedullary fixation devices. These devices differ considerably in their specifications and characteristics and an evaluation of their clinical results is warranted. The aim of this systematic review is to generate an overview of functional outcomes and complications in the management of DMCF per available intramedullary device.

Methods: A systematic review was conducted to identify all papers reporting functional outcomes, union rates and/or complications using an intramedullary fixation device for the management of midshaft clavicle fractures. Multiple databases and trial registries were searched from inception until February 2020. Meta-analysis was conducted based on functional outcomes and type of complication per type of intramedullary fixation device. Pooled estimates of functional outcomes scores and incidence of complications were calculated using a random effects model. Risk of bias and quality was assessed using the Cochrane risk of bias and ROBINS-I tools. The confidence in estimates were rated and described according to the recommendations of the GRADE working group.

Results: Sixty-seven studies were included in this systematic review. The majority of studies report on the use of Titanium Elastic Nails (TEN). At 12 months follow up the Titanium Elastic Nail and Sonoma CRx report an average Constant-Murley score of $94.4(95 \% \mathrm{Cl}$ 93-95) and 94.0 (95\%Cl 92-95) respectively (GRADE High). The most common reported complications after intramedullary fixation are implant-related and implant-specific. For the TEN, hardware irritation and protrusion, telescoping or migration, with a reported pooled incidence $20 \%(95 \% \mathrm{Cl} 14-26)$ and $12 \%$ (95\% Cl 8-18), are most common (GRADE Moderate). For the Rockwood/Hagie Pin, hardware irritation is identified as the most common complication with $22 \%$ (95\%Cl 13-35) (GRADE Low). The most common complication for the Sonoma CRx was cosmetic dissatisfaction in $6 \%(95 \% \mathrm{Cl} 2-17)$ of cases (GRADE Very low).

(Continued on next page)
\end{abstract}

\footnotetext{
* Correspondence: paul_hoogervorst@hotmail.com

'Department of Orthopedic Surgery, Radboud University Medical Center, P.O. Box 9101, 6500 HB Nijmegen, The Netherlands

2Department of Orthopedic Surgery, University of Minnesota, 2450 Riverside Avenue South, Suite R200, Minneapolis, MN 55454, USA

Full list of author information is available at the end of the article
}

C C The Author(s). 2020 Open Access This article is licensed under a Creative Commons Attribution 4.0 International License, which permits use, sharing, adaptation, distribution and reproduction in any medium or format, as long as you give appropriate credit to the original author(s) and the source, provide a link to the Creative Commons licence, and indicate if changes were made. The images or other third party material in this article are included in the article's Creative Commons licence, unless indicated otherwise in a credit line to the material. If material is not included in the article's Creative Commons licence and your intended use is not permitted by statutory regulation or exceeds the permitted use, you will need to obtain permission directly from the copyright holder. To view a copy of this licence, visit http://creativecommons.org/licenses/by/4.0/. The Creative Commons Public Domain Dedication waiver (http://creativecommons.org/publicdomain/zero/1.0/) applies to the data made available in this article, unless otherwise stated in a credit line to the data. 
(Continued from previous page)

Conclusion: Although most studies were of low quality, good functional results and union rates irrespective of the type of device are found. However, there are clear device-related and device-specific complications for each. The results of this systematic review and meta-analysis can help guide surgeons in choosing the appropriate operative strategy, implant and informing their patient.

Level of Evidence: IV

Keywords: Clavicle, Fracture, Complication, Survival, Failure, Function, Intramedullary

\section{Background}

Clavicle fractures are common fractures with an incidence reported of 59.3 per 100,000 person years [1]. Historically, these fractures were predominantly treated non-operatively. However, it has been reported that surgical treatment of displaced mid-shaft clavicle fractures (DMCF) leads to better union rates, improved early functional outcomes, and increased patient satisfaction [2-4]. The current gold standard in operative treatment is Open Reduction Internal Fixation (ORIF) using plates and screws. An alternative to this technique is internal fixation using intramedullary fixation devices. These devices aim to reduce the DMCF in a minimally invasive manner and thereby improving cosmetic satisfaction and union rates while lowering infection rates [5]. There are multiple different intramedullary devices available. Some of these devices are made out of rigid stainless steel while others consist of flexible titanium alloys. Some are not fixated within the bone while others are fixated on either one or both sides of the midshaft clavicle fracture. Since these devices differ considerably in their specifications and characteristics the array and distribution of complications and functional outcomes may vary as well.

The aim of this systematic review is to generate an overview of functional outcomes and complications in the management of DMCF per available intramedullary devices.

\section{Methods}

Electronic databases (PubMed, ScienceDirect, Embase and Cochrane) and clinical trial registries (ClinicalTrials.gov, controlled-trials.com (ISRCTN), Australian New Zealand Clinical Trials Registry (ANZCTR), Chinese Clinical Trial Registry (CCTR), EU Clinical Trials Register (EU-CTR) and The Netherlands National Trial Register (NTR)) were searched from their inception to February 2020. Keywords used to develop our search strategy were 'clavicle', 'fracture', 'intramedullary fixation'. The detailed search strategy is described in Additional file 1.

\section{Inclusion criteria}

All titles and abstracts were screened and study inclusion was decided on by two reviewers (PH/TvD). In case of discrepancy in study inclusion, disagreements were discussed until consensus on eligibility was reached. If disagreement persisted after discussion, consensus was met consulting GH. References of retrieved eligible articles were searched for supplementary studies. Studies meeting the following criteria were included:

- Studies describing the functional outcomes, with use of any type of intramedullary fixation for DMCF.

- Studies describing complications, with use of any type of intramedullary fixation for DMCF.

- Only original studies were included.

- Studies written in English, Dutch, and German.

- Studies concerning skeletally mature patients.

Abstracts, theses, case reports, biomechanical studies, surgical technique papers, editorials, letters and conference proceedings were not included. Studies using Kirschner wires and screws were excluded. Studies concerning intramedullary fixation for open fractures, pathological fractures, multi-trauma patients, floating shoulders, nonunions or mal-unions were also excluded.

\section{Data extraction}

Studies in the final study selection were divided into subgroups depending on type of implant and ranked according to their study design and level of evidence (Oxford Centre of Evidence Based Medicine) by 2 authors $(\mathrm{PH}, \mathrm{TvD})$. The level of evidence (LoE) rating is divided into 5 levels: level I indicates the highest evidence studies, level II high, level III moderate, level IV low and level V very low-evidence studies [6]. Disagreement between the reviewers concerning quality assessment was resolved by discussion.

Data from all included studies were extracted with respect to specific characteristics including title, author, year of publication, number of clavicles reported, type of fracture, intramedullary device used, length of follow-up, functional outcomes, and type and number of complications. Date were extracted and checked for accuracy by PH and TvD. Discrepancies were resolved by discussion. This study was conducted and reported in accordance with the reporting guidance provided in the Preferred Reporting Items for Systematic Reviews and Meta-Analyses (PRISMA) 
statement [7]. The protocol was prospectively registered in PROSPERO (CRD42018086518).

\section{Risk of bias and quality assessment}

The Cochrane risk of bias tool was used for assessing risk of bias in randomized trials.

The risk of bias tool covers six domains of bias: selection bias, performance bias, detection bias, attrition bias, reporting bias, and other bias. Within each domain, assessments are made for one or more items, which may cover different aspects of the domain, or different outcomes [8].

The ROBINS-I tool was used for assessing risk of bias in non-randomized studies of interventions [9]. This tool assesses seven domains through which bias might be introduced. The first two domains, covering confounding and selection of participants into the study, address issues before the start of the interventions. The third domain addresses classification of the interventions themselves. The other four domains address issues after the start of interventions: biases due to deviations from intended interventions, missing data, measurement of outcomes, and selection of the reported result.

Publication bias was assessed only if 10 or more studies were included in the meta-analysis using funnel plots and Egger's (for continuous outcomes) and Peters' test (for proportions) for funnel plot asymmetry [10-12]. Sensitivity analyses were performed to assess the influence of study quality when there was more than 1 high quality study available according to the ROBINS-I.

The confidence in estimates were rated and described according to the recommendations of the GRADE working group as each outcome was assessed for potential risk of bias, inconsistency, imprecision, indirectness and publication bias [13].

\section{Data analysis}

A meta-analysis was performed whenever three or more studies per intramedullary device that reported on a functional outcome or type of complication could be included.

Despite anticipated heterogeneity, the individual study proportions were pooled. Pooled estimates with their corresponding 95\% confidence intervals were calculated using logit transformation (complications) or using untransformed data (functional outcome scores) within a random effects model framework. A continuity correction of 0.5 was applied if a study had an event probability of either 0 or 1 . This continuity correction is used both to calculate individual study results with confidence limits and to conduct the meta-analysis. Heterogeneity of combined study results was assessed by $\mathrm{I}^{2}$, and its connected Chi-square test for heterogeneity, and the corresponding 95\% confidence intervals were calculated. Restricted maximum likelihood was used to estimate the heterogeneity variance. 95\% Prediction intervals were calculated to present the expected range of true effects in similar studies [14].

Statistical analyses were performed using $\mathrm{R}$ version 3.4.4 (R Foundation for Statistical Computing, Vienna, Austria) with package 'meta'.

\section{Results}

The search strategy retrieved 368 unique records. Subsequent selection procedure resulted in 75 eligible articles of which 67 studies could be included in this systematic review and 62 in the meta-analysis (Additional file 2). In total, 10 studies concerning the Rockwood (DePuy, Warsaw, IN, USA) and Hagie pin (Smith \& Nephew, Memphis, TN, USA) were identified and included in the analysis (two level I, $[15,16]$ two level III $[17,18]$ and six level IV [19-24] studies). These devices were evaluated together since they are essentially the same; they both consist of the exact same stainless-steel pin, with a cancellous and machine thread end, and two nuts. The only difference between the two is that the Rockwood pin also has a trocar point on the machine thread end of the pin. Concerning the Titanium Elastic Nail (TEN) (Depuy Synthes, Warsaw, IN, USA or Stryker, Kalamazoo, MI, USA) the 43 studies that were incorporated in the analysis were comprised of seven level I, [25-31] eight level II, [32-39] eleven level III [40-50] and seventeen level IV [5, 51-66] studies. Another type of fixation described was the Sonoma CRx (Arthrex, Naples, FL, USA) for which 6 studies (three level I, [67-69] one level II, [70] one level III [71] and one level IV [72]) were identified. Less frequently described intramedullary fixation devices were the threaded titanium elastic nails (Kang Li Min Medical Devices Co. Ltd., Tianjin, China), [73-75] the Knowles pin (Zimmer Biomet, Warshaw, IN, USA) [76-79] and one study describing a second generation Titanium elastic nail (Puwei Medical Appliances Inc., Shanghai, China) [80]. Table 1 displays study characteristics including population description, type of intramedullary device, functional outcome scores, and type and number of complications.

\section{Risk of bias assessment}

The results of the Cochrane risk of bias tool are summarized in Table 2 and shows high risk of bias in domains 3 and 4 assessing performing and detection bias. The results of the ROBINS-I risk of bias assessment, summarized in Table 3 shows that the overall ROBINS-I score for most studies were subject to serious or critical risk of bias.

\section{Studies concerning the Rockwood pin and Hagie pin}

All studies identified concerning these devices described an identical surgical technique. All pins were 


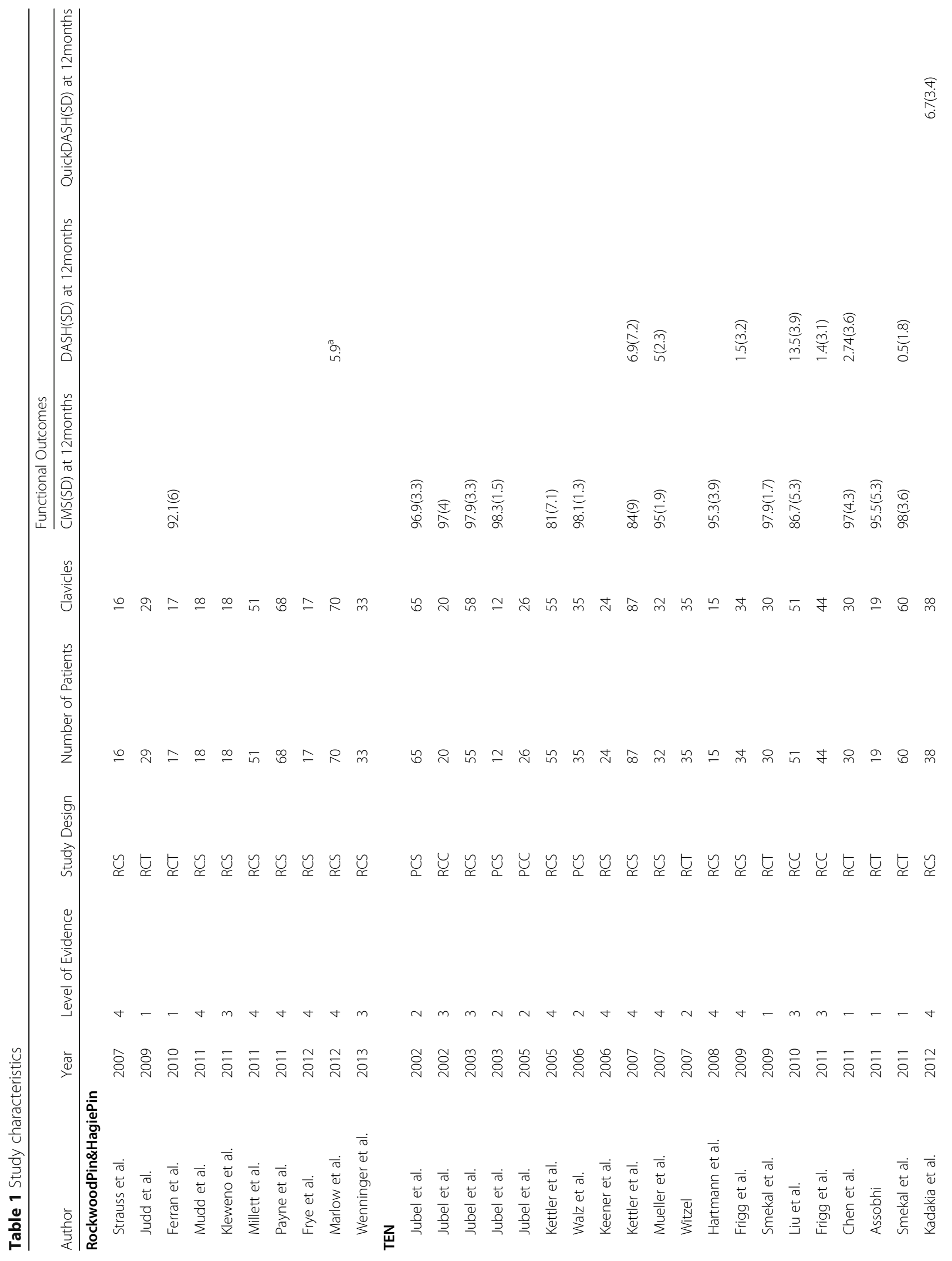




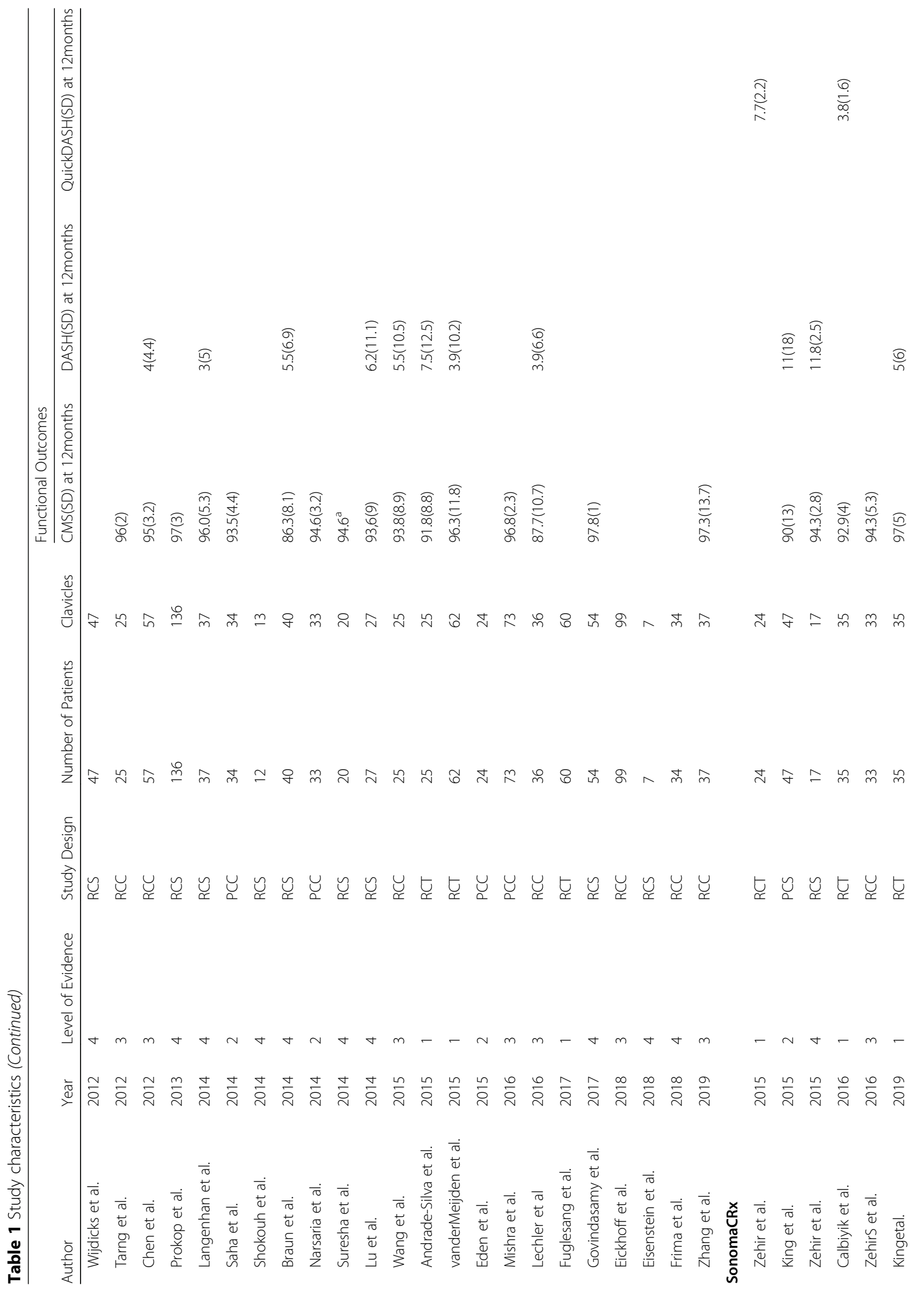




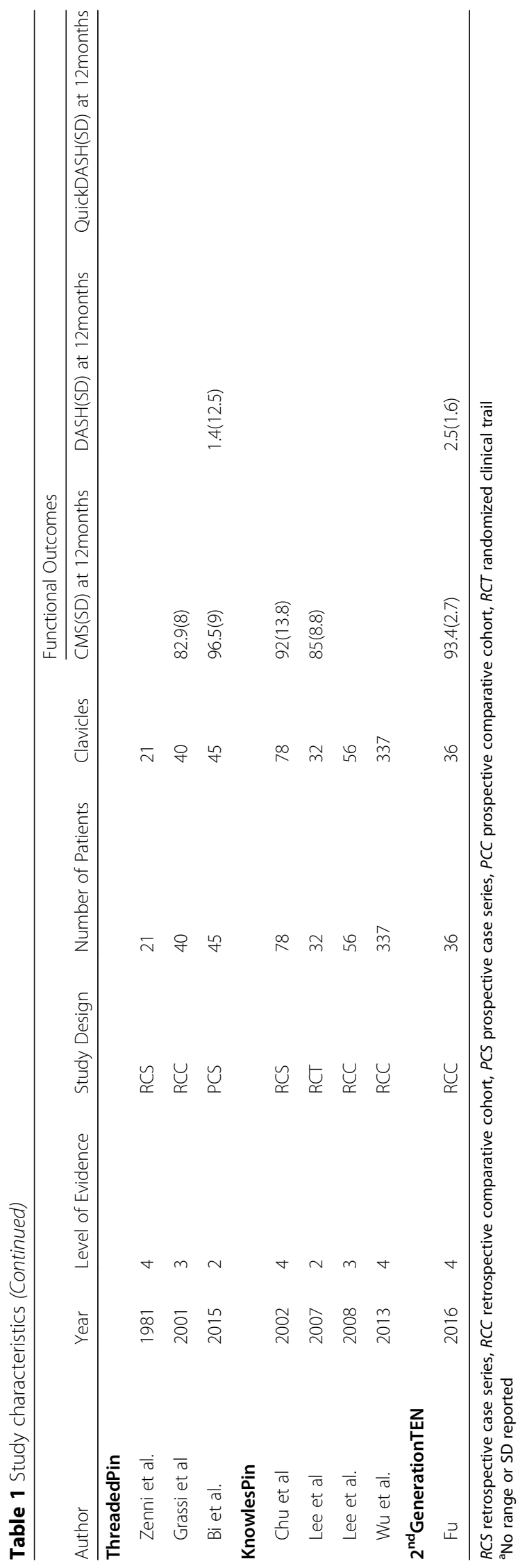


Hoogervorst et al. BMC Musculoskeletal Disorders

(2020) 21:395

Page 7 of 20

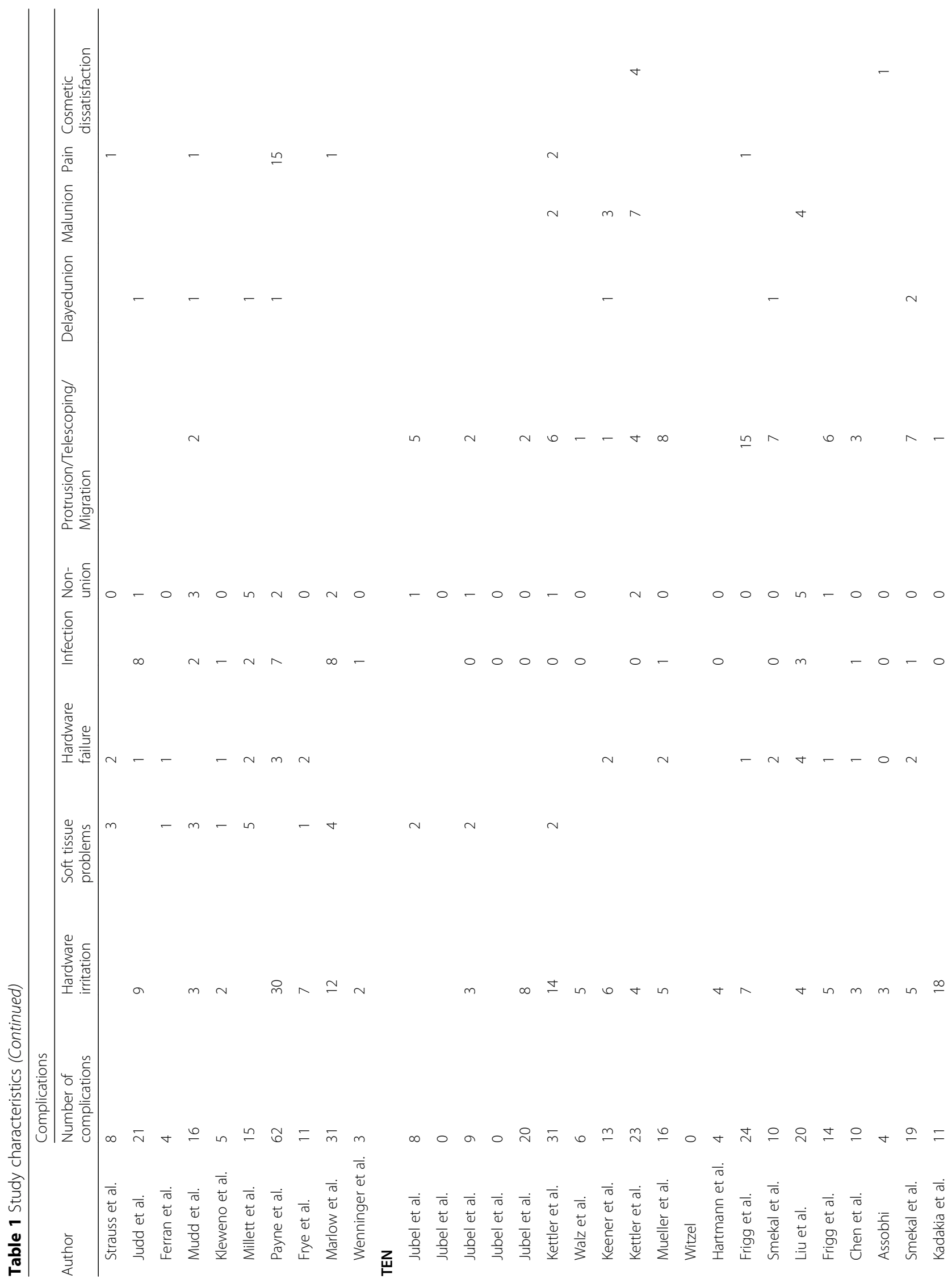


Hoogervorst et al. BMC Musculoskeletal Disorders

(2020) 21:395

Page 8 of 20

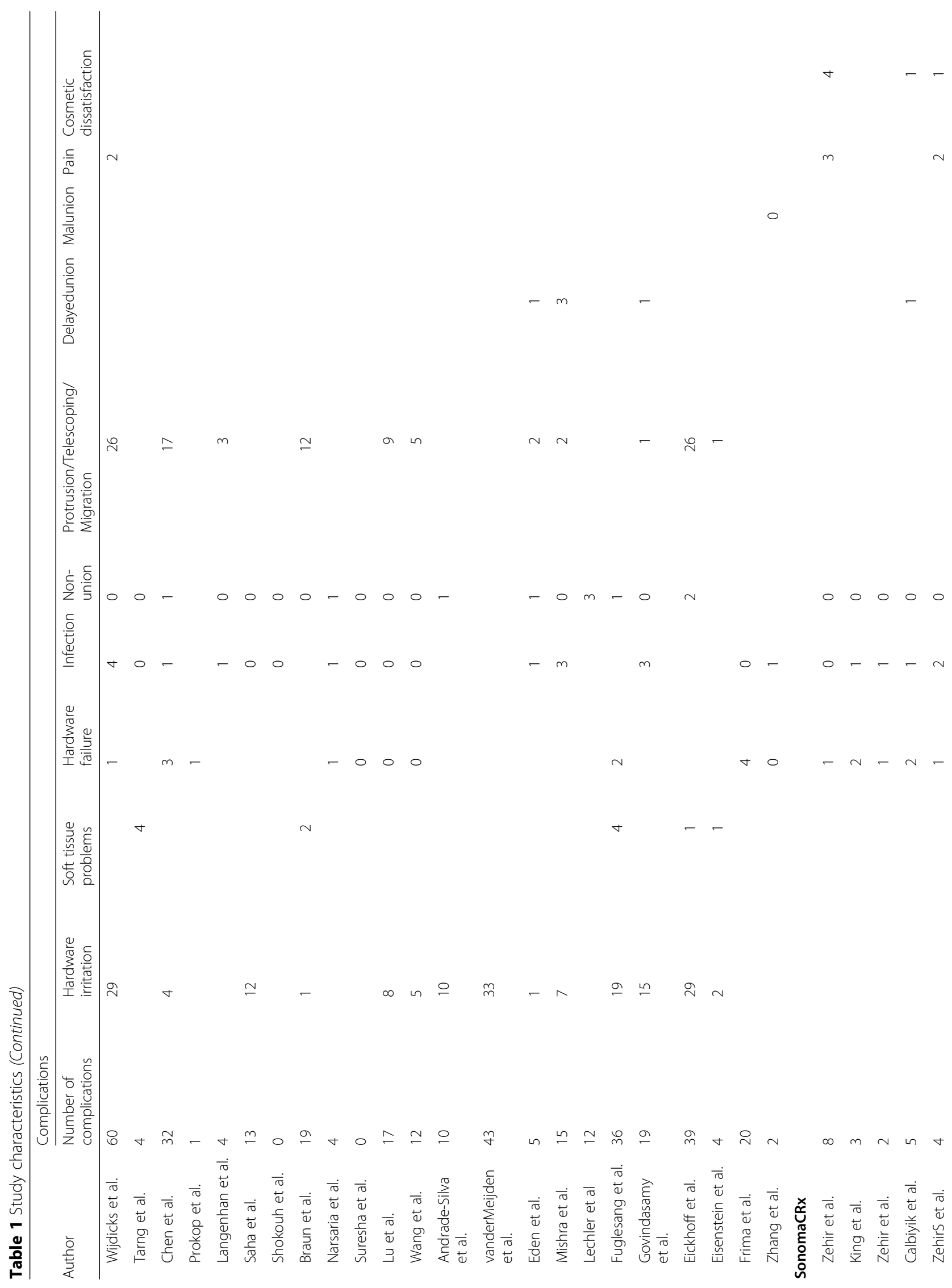




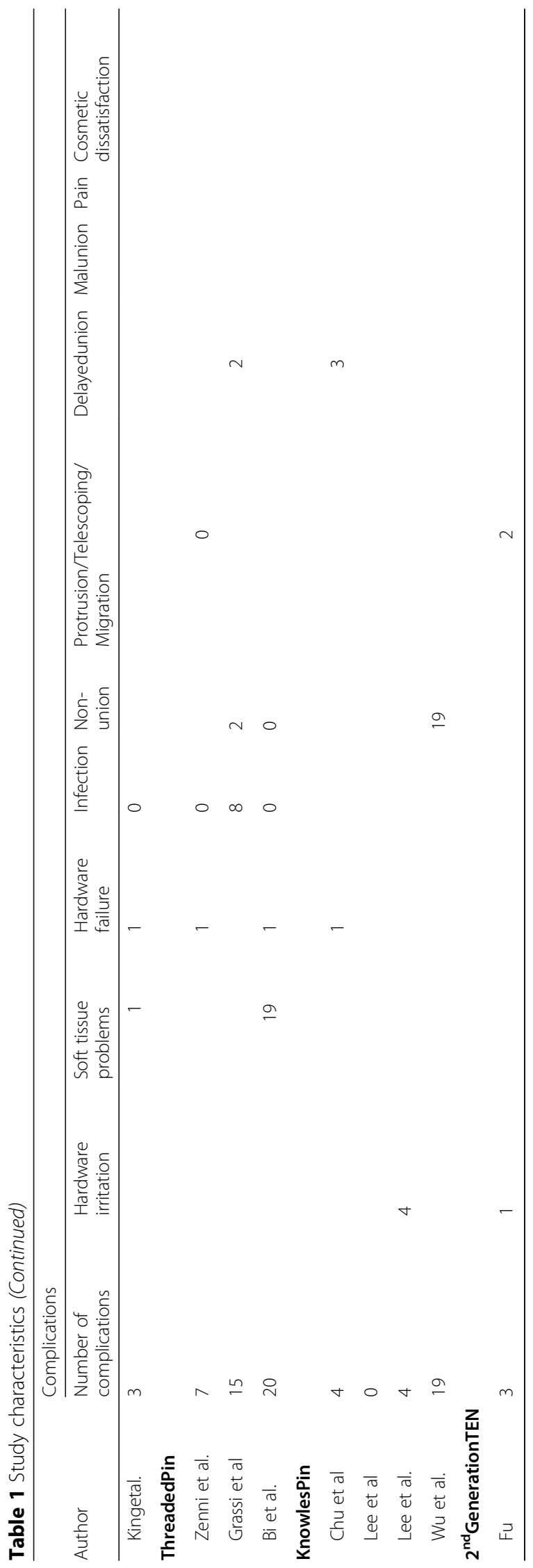


Table 2 Cochrane risk of bias assessment of randomized trials

\begin{tabular}{|c|c|c|c|c|c|c|c|c|}
\hline & & 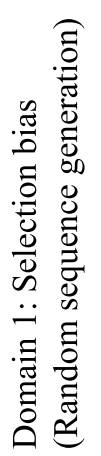 & 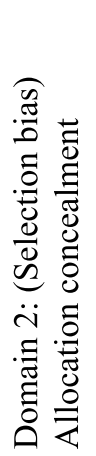 & 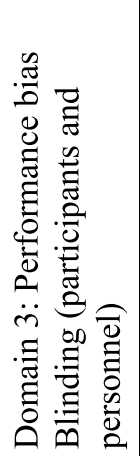 & 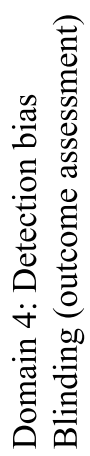 & 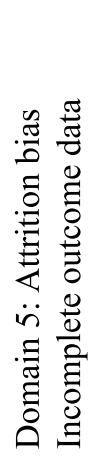 & 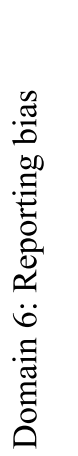 & 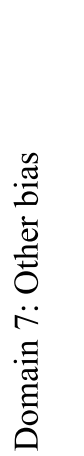 \\
\hline \multicolumn{9}{|l|}{ Sonoma CRx } \\
\hline \multirow{3}{*}{$\begin{array}{l}\text { Zehir et al. } \\
\text { Calbiyik et al. } \\
\text { King et al. }\end{array}$} & \multirow{3}{*}{$\begin{array}{l}2015 \\
2016 \\
2019\end{array}$} & + & & & & $?$ & $?$ & \\
\hline & & + & 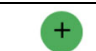 & & & + & $?$ & \\
\hline & & + & & & & & $?$ & \\
\hline \multicolumn{9}{|l|}{ Rockwood \& Hagie Pin } \\
\hline \multirow{2}{*}{$\begin{array}{l}\text { Judd et al. } \\
\text { Ferran et al. }\end{array}$} & \multirow{2}{*}{$\begin{array}{l}2009 \\
2010\end{array}$} & + & & & & $?$ & $?$ & \\
\hline & & $?$ & & & & + & 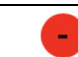 & \\
\hline \multicolumn{9}{|l|}{$T E N$} \\
\hline Witzel & 2007 & $?$ & $?$ & & & $?$ & $?$ & \\
\hline Smekal et al. & 2009 & + & + & & & & $?$ & \\
\hline Chen et al. & 2011 & $?$ & ? & & & $?$ & $?$ & \\
\hline Asshobi & 2011 & $?$ & $?$ & & & + & $?$ & \\
\hline \multirow{2}{*}{$\begin{array}{l}\text { Smekal et al } \\
\text { Andrade-Silva }\end{array}$} & 2011 & + & & & & $?$ & $?$ & \\
\hline & 2015 & + & + & & & + & + & \\
\hline \multicolumn{2}{|c|}{ Van der Meijden et al. 2015} & + & + & & & + & + & \\
\hline Fuglesang et al. & 2017 & + & + & & & + & $?$ & \\
\hline \multicolumn{9}{|l|}{ Knowles Pin } \\
\hline Lee et al. & 2007 & & & & & $?$ & & 7 \\
\hline
\end{tabular}

Green low risk, Red high risk, Yellow Unknown Risk

Constant-Murley $(92.1 \pm 6)$ [15] or DASH (5.9) [19]. Other functional outcome scores reported were the Oxford Shoulder Score $(45.2 \pm 2.3)$, [15] L'Insalata (95.5 \pm 7.3$)$, [16] and ASES (88.6 and 89) [20, 24].

\section{Meta-analysis:}

It was not possible to perform a meta-analysis for functional outcomes. A meta-analysis was performed for 6 different complications. Data from 10 studies were used to evaluate nonunion followed by data from 7 studies for infection. Seven studies reported hardware irritation, soft tissue problems [15, 17, 1921, 23, 24] and hardware failure [15-17, 20, 22-24]. Four studies were included in a meta-analysis for persistent pain. (Fig. 1) The highest pooled incidences were found for complications hardware irritation (22, 95\%CI 13-35 in 253 clavicles), soft tissue problems (9, 95\%CI 6-13 in 207 clavicles) and infection (9, 95\% CI 5-16 in 287 clavicles). A pooled incidence of unspecified persistent pain was reported in $6 \%$ 
Table 3 ROBINS-I assessing risk of bias in non-randomized studies of interventions

\begin{tabular}{|c|c|c|c|c|c|c|c|c|c|}
\hline Author & Year & $\begin{array}{l}\text { Domain 1: } \\
\text { Confounding }\end{array}$ & $\begin{array}{l}\text { Domain 2: } \\
\text { Selection of } \\
\text { participants }\end{array}$ & $\begin{array}{l}\text { Domain 3: } \\
\text { Classification of } \\
\text { intervention }\end{array}$ & $\begin{array}{l}\text { Domain 4: } \\
\text { Deviation from } \\
\text { interventions }\end{array}$ & $\begin{array}{l}\text { Domain 5: } \\
\text { Missing } \\
\text { data } \\
\text { Domain }\end{array}$ & $\begin{array}{l}\text { Domain 6: } \\
\text { Measurement } \\
\text { of outcomes }\end{array}$ & $\begin{array}{l}\text { Domain } 7: \\
\text { Selection of } \\
\text { reported results }\end{array}$ & $\begin{array}{l}\text { ROBINS-I } \\
\text { overall }\end{array}$ \\
\hline
\end{tabular}

\section{Sonoma CRx}

Zehir et al. $\quad 20152$

King et al. $\quad 20153$

Zehir et al. 20153

Calbiyik et al. $2016 \quad 2$

Zehir S et al. 20163

Domain

Rockwood Pin \& Hagie Pin

$\begin{array}{llll}\text { Strauss et al. } & 2007 & 4 & 3 \\ \text { Judd et al. } & 2009 & 2 & 2 \\ \text { Ferran et al. } & 2010 & 2 & 2 \\ \text { Mudd et al. } & 2011 & 3 & 3 \\ \text { Kleweno et al. } & 2011 & 3 & 2 \\ \text { Millett et al. } & 2011 & 3 & 3 \\ \text { Payne et al. } & 2011 & 3 & 2 \\ \text { Frye et al. } & 2012 & 3 & 3 \\ \text { Marlow et al. } & 2012 & 3 & 3 \\ \text { Wenninger } & 2013 & 3 & 2 \\ \text { et al. } & & \end{array}$

2
2
2
1
2

1
1
1
1
1

3
1
2
2
2
3
2
3
2
2

TEN

\begin{tabular}{|c|c|c|c|c|c|c|c|c|c|}
\hline Jubel et al. & 2002 & 2 & 2 & 1 & 1 & 2 & 2 & 2 & 2 \\
\hline Jubel et al. & 2002 & 2 & 3 & 2 & 1 & 1 & 2 & 2 & 3 \\
\hline Jubel et al. & 2003 & 3 & 3 & 2 & 1 & 2 & 2 & 3 & 3 \\
\hline Jubel et al. & 2003 & 3 & 3 & 1 & 1 & 2 & 2 & 2 & 3 \\
\hline Jubel et al. & 2005 & 2 & 3 & 1 & 1 & 1 & 2 & 2 & 3 \\
\hline Kettler et al. & 2005 & 4 & 3 & 1 & 1 & 2 & 2 & 2 & 4 \\
\hline Walz et al. & 2006 & 2 & 2 & 1 & 1 & 1 & 2 & 2 & 2 \\
\hline Keener et al. & 2006 & 4 & 3 & 2 & 1 & 3 & 2 & 3 & 3 \\
\hline Kettler et al. & 2007 & 3 & 3 & 2 & 1 & 2 & 2 & 2 & 3 \\
\hline Mueller et al. & 2007 & 2 & 2 & 1 & 1 & 1 & 2 & 1 & 2 \\
\hline Witzel & 2007 & 3 & 2 & 2 & 1 & 2 & 2 & 2 & 3 \\
\hline $\begin{array}{l}\text { Hartmann } \\
\text { et al. }\end{array}$ & 2008 & 3 & 3 & 2 & 1 & 2 & 2 & 3 & 3 \\
\hline Frigg et al. & 2009 & 3 & 2 & 1 & 2 & 2 & 2 & 3 & 3 \\
\hline Smekal et al. & 2009 & 2 & 2 & 1 & 1 & 1 & 2 & 2 & 2 \\
\hline Liu et al. & 2010 & 3 & 3 & 2 & 1 & 2 & 2 & 3 & 3 \\
\hline Frigg et al. & 2011 & 2 & 2 & 1 & 1 & 3 & 2 & 2 & 3 \\
\hline Chen et al. & 2011 & 2 & 2 & 1 & 1 & 1 & 2 & 2 & 2 \\
\hline Assobhi & 2011 & 2 & 2 & 2 & 1 & 1 & 2 & 2 & 2 \\
\hline Smekal et al. & 2011 & 2 & 2 & 1 & 1 & 1 & 2 & 2 & 2 \\
\hline Kadakia et al. & 2012 & 4 & 3 & 2 & 1 & 2 & 3 & 2 & 4 \\
\hline Wijdicks et al. & 2012 & 3 & 2 & 3 & 1 & 2 & 3 & 2 & 3 \\
\hline Tarng et al. & 2012 & 3 & 3 & 3 & 1 & 2 & 2 & 2 & 3 \\
\hline Chen et al. & 2012 & 3 & 3 & 2 & 1 & 2 & 2 & 2 & 3 \\
\hline
\end{tabular}


Table 3 ROBINS-I assessing risk of bias in non-randomized studies of interventions (Continued)

\begin{tabular}{|c|c|c|c|c|c|c|c|c|c|}
\hline Author & Year & $\begin{array}{l}\text { Domain 1: } \\
\text { Confounding }\end{array}$ & $\begin{array}{l}\text { Domain 2: } \\
\text { Selection of } \\
\text { participants }\end{array}$ & $\begin{array}{l}\text { Domain 3: } \\
\text { Classification of } \\
\text { intervention }\end{array}$ & $\begin{array}{l}\text { Domain 4: } \\
\text { Deviation from } \\
\text { interventions }\end{array}$ & $\begin{array}{l}\text { Domain 5: } \\
\text { Missing } \\
\text { data } \\
\text { Domain }\end{array}$ & $\begin{array}{l}\text { Domain 6: } \\
\text { Measurement } \\
\text { of outcomes }\end{array}$ & $\begin{array}{l}\text { Domain } 7 \text { : } \\
\text { Selection of } \\
\text { reported results }\end{array}$ & $\begin{array}{l}\text { ROBINS-I } \\
\text { overall }\end{array}$ \\
\hline Prokop et al. & 2013 & 3 & 3 & 2 & 1 & 3 & 2 & 3 & 3 \\
\hline $\begin{array}{l}\text { Langenhan } \\
\text { et al. }\end{array}$ & 2014 & 2 & 3 & 2 & 1 & 2 & 2 & 3 & 3 \\
\hline Saha et al. & 2014 & 3 & 2 & 2 & 1 & 2 & 2 & 2 & 3 \\
\hline $\begin{array}{l}\text { Shokouh } \\
\text { et al. }\end{array}$ & 2014 & 2 & 3 & 2 & 1 & 2 & 3 & 2 & 3 \\
\hline Braun et al. & 2014 & 2 & 3 & 2 & 1 & 2 & 2 & 2 & 3 \\
\hline Narsaria et al. & 2014 & 2 & 2 & 1 & 1 & 2 & 2 & 2 & 2 \\
\hline Suresha et al. & 2014 & 3 & 3 & 2 & 1 & 2 & 2 & 2 & 3 \\
\hline Lu et al. & 2014 & 2 & 3 & 1 & 1 & 2 & 2 & 2 & 3 \\
\hline Wang et al. & 2015 & 2 & 3 & 1 & 1 & 2 & 2 & 2 & 3 \\
\hline $\begin{array}{l}\text { Andrade-Silva } \\
\text { et al. }\end{array}$ & 2015 & 2 & 1 & 1 & 1 & 1 & 2 & 1 & 2 \\
\hline $\begin{array}{l}\text { van der } \\
\text { Meijden et al. }\end{array}$ & 2015 & 2 & 1 & 1 & 1 & 1 & 2 & 1 & 2 \\
\hline Eden et al. & 2015 & 3 & 2 & 2 & 1 & 2 & 2 & 2 & 3 \\
\hline Mishra et al. & 2016 & 2 & 2 & 2 & 1 & 2 & 2 & 2 & 2 \\
\hline Lechler et al & 2016 & 3 & 3 & 2 & 1 & 2 & 2 & 2 & 3 \\
\hline $\begin{array}{l}\text { Fuglesang } \\
\text { et al. }\end{array}$ & 2017 & 2 & 2 & 1 & 1 & 2 & 2 & 2 & 2 \\
\hline $\begin{array}{l}\text { Govindasamy } \\
\text { et al. }\end{array}$ & 2017 & 3 & 3 & 2 & 1 & 3 & 2 & 2 & 2 \\
\hline Eickhoff et al. & 2018 & 2 & 2 & 1 & 1 & 2 & 2 & 2 & 2 \\
\hline $\begin{array}{l}\text { Eisenstein } \\
\text { et al. }\end{array}$ & 2018 & 3 & 2 & 2 & 1 & 2 & 2 & 2 & 3 \\
\hline Frima et al. & 2018 & 2 & 2 & 2 & 1 & 2 & 2 & 2 & 2 \\
\hline Zhang et al. & 2019 & 2 & 3 & 2 & 1 & 3 & 3 & 3 & 3 \\
\hline \multicolumn{10}{|l|}{ Threaded Pin } \\
\hline Zenni et al. & 1981 & 4 & 4 & 2 & 1 & 2 & 3 & 2 & 4 \\
\hline Grassi et al & 2001 & 3 & 3 & 2 & 1 & 2 & 2 & 2 & 3 \\
\hline Bi et al. & 2015 & 2 & 2 & 2 & 1 & 2 & 2 & 2 & 2 \\
\hline \multicolumn{10}{|l|}{ Knowles Pin } \\
\hline Chu et al & 2002 & 3 & 3 & 2 & 3 & 3 & 2 & 3 & 3 \\
\hline Lee et al & 2007 & 3 & 2 & 2 & 1 & 2 & 2 & 2 & 3 \\
\hline Lee et al. & 2008 & 3 & 3 & 2 & 1 & 2 & 2 & 2 & 3 \\
\hline Wu et al. & 2013 & 3 & 2 & 2 & 1 & 2 & 3 & 2 & 3 \\
\hline
\end{tabular}

1 low risk of bias, 2 moderate risk of bias, 3 serious risk of bias, 4 critical risk of bias

(95\%CI 2-20 in 172 clavicle) of cases. The pooled incidence of hardware failure and nonunion was 6\% (95\% CI $3-10$ in 216 clavicles) and 3\% (95\% CI 1-8 in 337 clavicles) respectively.

The confidence in the estimates from the metaanalyses according to GRADE ranged between low and very low (Table 4 and Additional file 3).

\section{Studies concerning the titanium elastic nail (TEN)}

The first reports on using TEN in the treatment of DMCF dated from 2002 [35]. TENs with a diameter varying between 2 and $3.5 \mathrm{~mm}$ were used. Closed reduction rates were reported in 28 of 35 studies. The rates ranged from 15\% [46] to $93 \%$ [27]. Most studies report a routine removal of the TEN in all cases mostly through a second surgical 


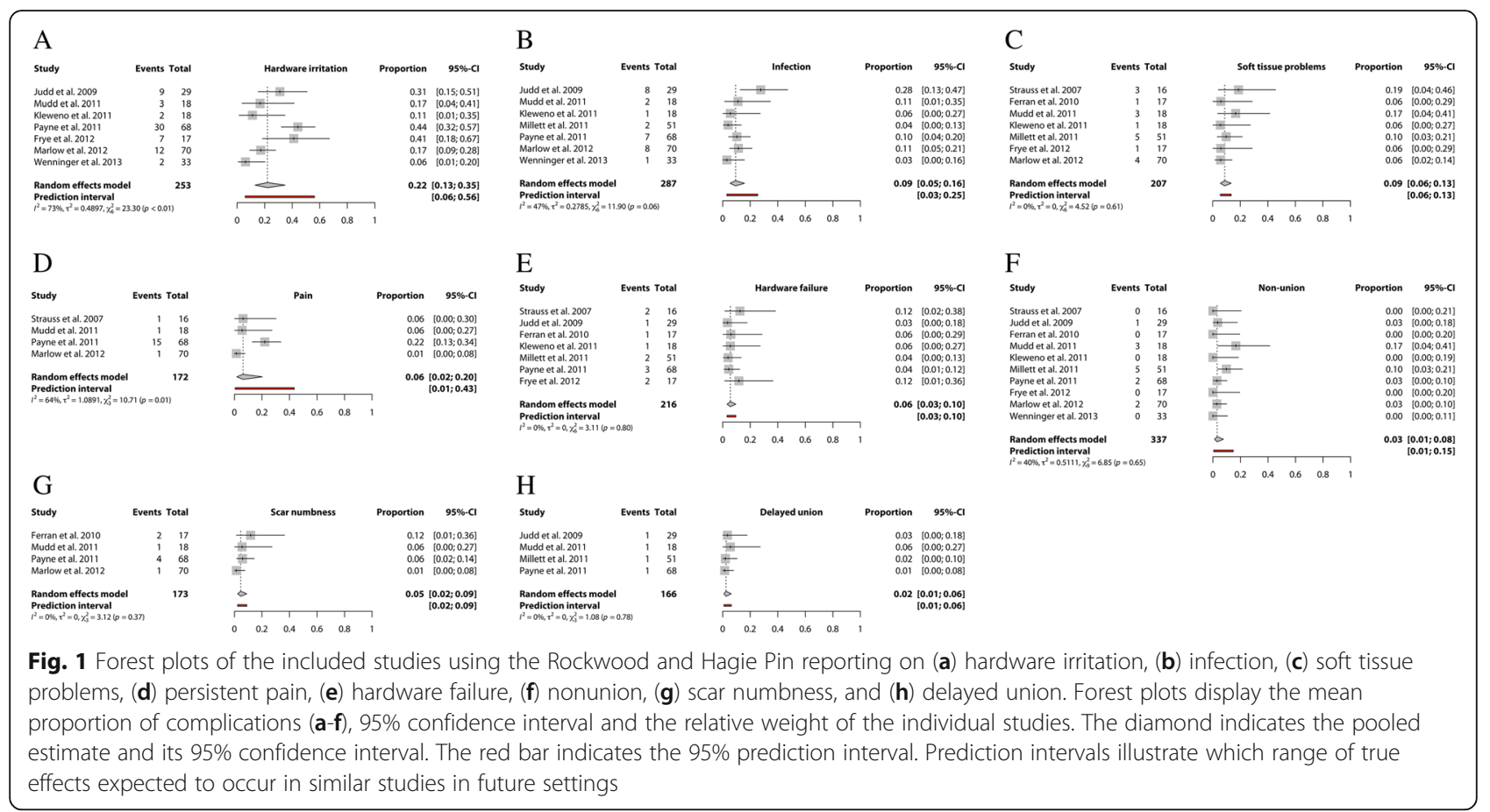

intervention but also removal under local anesthesia was described. The earliest routine nail removal was performed at 3 months [56] and the latest on average at 8.8 months [25].

\section{Meta-analysis:}

A meta-analysis was performed for functional outcomes based on 30 studies reporting the ConstantMurley Score and 15 studies reporting a DASH score. (Fig. 2) The pooled data for the Constant-Murley score and DASH score at 12 months is 94.4 (95\% CI 93.4-95.4 in 1290 clavicles) and 4.6 (95\%CI $2.6-6.7$ in 647 clavicles), respectively (Fig. 2). The confidence in the estimates from the meta-analyses according to GRADE concerning the functional outcomes were considered high due to the consistency and precision of the data in combination with the large number of clavicles involved (Table 4 and Additional file 3). The functional outcomes of two studies were not included in the meta-analysis [28, 31]. Fuglesang et al. [28] report the Constant-Murley and DASH scores of 60 TENs only by means of a line graph and van der Meijden et al. [31] report in-text Constant-Murley scores at 1 year follow up that differ from the line graph displayed. Visual evaluation of the line graphs however seems similar to the pooled incidences from the meta-analysis.

Data from 43 studies were pooled in the metaanalysis for evaluating complications rates using the TEN. Twenty-nine studies reported on infection, 29 studies on hardware irritation, 25 studies on protrusion/telescoping/migration, 19 on hardware failure, 12 on nonunion, 8 on soft tissue problems, 5 on malunion and 3 on pain. (Fig. 3) The two most common complications reported, protrusion/telescoping/migration and hardware irritation, are implant-related. The pooled incidence was $12 \%$ (95\%CI 8-18 in 1105 clavicles) and $20 \%$ (95\%CI 14-26 in 1273 clavicles), respectively.

Malunion after surgical management by means of a TEN was reported in 7\% (95\%CI 4-11 in 193 clavicles) and hardware failure was $3 \%(95 \% \mathrm{CI} 2-5$ in 800 clavicles). Pooled infection incidence was $2 \%$ (95\%CI $0-3$ in 1084 clavicles) and the pooled incidence of a nonunion using a TEN was $3 \%$ (95\%CI $2-4$ in 1436 clavicles). The confidence in the estimates from the meta-analyses according to GRADE concerning the functional outcomes ranged from moderate to very low (Table 4 and Additional file 3).

\section{Studies concerning the Sonoma CRx Meta-analysis}

Six studies were included in the meta-analysis. Data from 5 studies were pooled for functional outcomes using the Constant-Murley score. The pooled ConstantMurley score at 12 months was 94.0 (95\%CI 92-96 in 167 clavicles). Six studies reported on nonunion, infection and hardware failure. Three studies reported cosmetic dissatisfaction. (Fig. 4) The pooled incidence for cosmetic dissatisfaction was highest at 6\% (95\%CI 2-17 in 92 clavicles), followed by of hardware failure (4\%; 95\% CI 2-8 in 191 clavicles) and infection (3\%; 95\% CI 17 in 191 clavicles). No reports of non-union using the 
Table 4 Summary of findings table including GRADE

\begin{tabular}{|c|c|c|c|c|c|}
\hline Device & Outcome & No. of Studies & No. of Clavicles & Effect estimate $(95 \% \mathrm{CI}))$ & Quality of evidence (GRADE) \\
\hline \multicolumn{6}{|c|}{ Rockwood Pin \& Hagie Pin } \\
\hline & Hardware Irritation & 7 & 253 & $0.22(0.13-0.35)$ & $\oplus \oplus \odot \odot$ LOW \\
\hline & Infection & 7 & 287 & $0.09(0.05-0.16)$ & $\oplus \oplus \odot \odot$ LOW \\
\hline & Soft Tissue Problems & 7 & 207 & $0.09(0.06-0.13)$ & $\oplus \oplus \odot \odot$ LOW \\
\hline & Pain & 4 & 172 & $0.06(0.02-0.20)$ & $\oplus \odot \odot \odot$ VERY LOW \\
\hline & Hardware Failure & 7 & 216 & $0.06(0.03-0.10)$ & $\oplus \oplus \odot \odot$ LOW \\
\hline & Nonunion & 6 & 191 & $0.00(0.00-0.04)$ & $\oplus \oplus \odot \odot$ LOW \\
\hline & Scar Numbness & 4 & 173 & $0.05(0.02-0.09)$ & $\oplus \odot \odot \odot$ VERY LOW \\
\hline & Delayed Union & 4 & 166 & $0.02(0.01-0.06)$ & $\oplus \odot \odot \odot$ VERY LOW \\
\hline \multicolumn{6}{|l|}{ TEN } \\
\hline & CMS & 29 & 1270 & $94.40(93.43-95.37)$ & $\oplus \oplus \oplus \oplus \mathrm{HIGH}$ \\
\hline & DASH & 15 & 647 & $4.65(2.61-6.68)$ & $\oplus \oplus \oplus \oplus \mathrm{HIGH}$ \\
\hline & Hardware Irritation & 30 & 1273 & $0.20(0.14-0.26)$ & $\oplus \oplus \oplus \odot$ MODERATE \\
\hline & Protrusion & 25 & 1105 & $0.12(0.08-0.18)$ & $\oplus \oplus \oplus \odot$ MODERATE \\
\hline & Malunion & 3 & 193 & $0.07(0.04-0.11)$ & $\oplus \oplus \odot \odot$ LOW \\
\hline & Soft Tissue Problems & 8 & 406 & $0.04(0.03-0.08)$ & $\oplus \odot \odot \odot$ VERY LOW \\
\hline & Pain & 3 & 136 & $0.04(0.02-0.09)$ & $\oplus \odot \odot \odot$ VERY LOW \\
\hline & Nonunion & 36 & 1436 & $0.03(0.02-0.04)$ & $\oplus \oplus \oplus \odot$ MODERATE \\
\hline & Hardware Failure & 19 & 800 & $0.03(0.02-0.05)$ & $\oplus \oplus \odot \odot$ LOW \\
\hline & Delayed Union & 6 & 265 & $0.03(0.02-0.06)$ & $\oplus \odot \odot \odot$ VERY LOW \\
\hline & Infection & 29 & 1084 & $0.02(0.01-0.03)$ & $\oplus \oplus \oplus \odot$ MODERATE \\
\hline \multicolumn{6}{|c|}{ Sonoma CRx } \\
\hline & CMS & 5 & 167 & 94.03 (92.31-95.76) & $\oplus \oplus \oplus \odot$ MODERATE \\
\hline & DASH & 3 & 99 & $9.16(3.94-14.37)$ & $\oplus \oplus \oplus \odot$ MODERATE \\
\hline & Cosmetic Dissatisfaction & 3 & 92 & $0.06(0.02-0.17)$ & $\oplus \odot \odot \odot$ VERY LOW \\
\hline & Hardware Failure & 6 & 191 & $0.04(0.02-0.08)$ & $\oplus \oplus \odot \odot$ LOW \\
\hline & Infection & 6 & 191 & $0.03(0.01-0.07)$ & $\oplus \oplus \odot \odot$ LOW \\
\hline & Nonunion & 6 & 191 & $0.00(0.00-0.04)$ & $\oplus \oplus \odot \odot$ LOW \\
\hline \multicolumn{6}{|c|}{ Threaded Pin } \\
\hline & Infection & 3 & 106 & $0.01(0.00-0.64)$ & $\oplus \odot \odot \odot$ Very Low \\
\hline
\end{tabular}

GRADE Working Group grades of evidence

High certainty: We are very confident that the true effect lies close to that of the estimate of the effect

Moderate certainty: We are moderately confident in the effect estimate: The true effect is likely to be close to the estimate of the effect, but there is a possibility that it is substantially different

Low certainty: Our confidence in the effect estimate is limited: The true effect may be substantially different from the estimate of the effect

Very low certainty: We have very little confidence in the effect estimate: The true effect is likely to be substantially different from the estimate of effect

Sonoma CRx were reported, the pooled incidence was $0 \%$ (95\%CI 0-4 in 191 clavicles).

Two studies reported on persistent pain as a complication $[68,71]$ and 1 study mentions the occurrence of a delayed union [67].

The confidence in the estimates from the metaanalyses according to GRADE concerning the functional outcomes were considered moderate. Although the results were consistent, the data originate from very limited group of authors. The confidence in the other meta- analyses according to GRADE were low to very low (Table 4 and Additional file 3).

\section{Studies concerning a threaded elastic nail}

Meta-analysis was only possible for infection [73-75] and the pooled incidence was 5\% $(95 \%$ CI $1-34$ in 106 clavicles).

The confidence in the estimates from this metaanalysis according to GRADE was very low (Table 4 and 


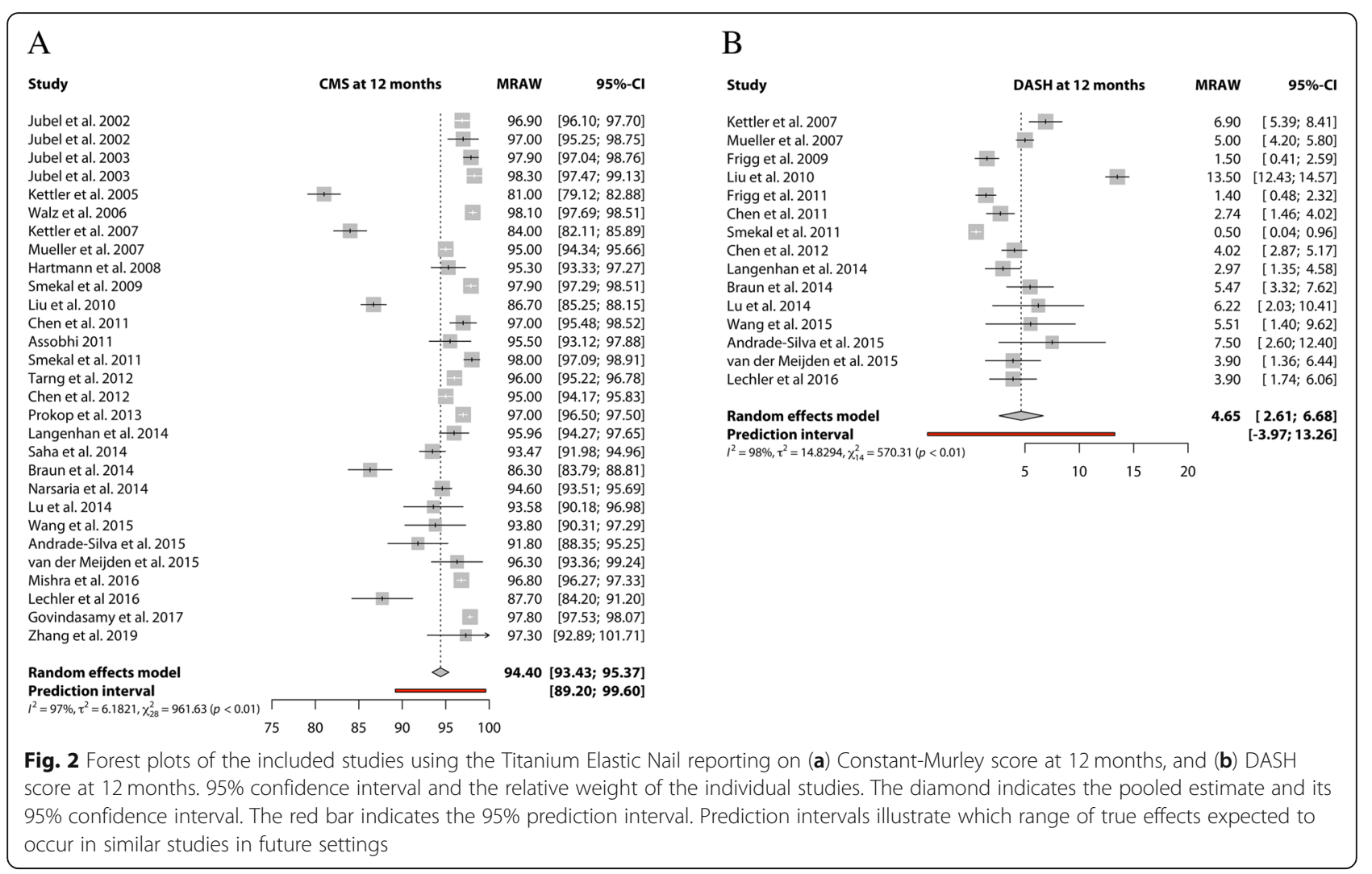

Additional file 3: Additional file 3). Other complications described for this type of fixation were soft tissue problems, delayed union and malunion. (Table 2).

\section{Studies concerning the Knowles pin}

One study reported 4 hardware irritations in 56 patients [77] and another study reported a nonunion rate of 5.6\% [79]. No meta-analysis was possible for this device type.

\section{Study concerning a second generation TEN}

One level IV study described the results of a second generation TEN in 36 patients [80]. It reported a Constant-Murley score of 93.4 (SD2.7) and 3 complications; 2 protrusions and 1 hardware irritation.

\section{Sensitivity analysis}

The sensitivity analysis including only studies with a low risk of bias showed our results to be robust. The complete results of the sensitivity analysis can be found in Additional file 4.

\section{Publication bias}

In those cases that publication bias could be assessed, its presence was unlikely based on the inspection of the funnel plots and evaluation of Egger's or Peters' tests.
Only for the Constant Murley and DASH scores the tests for funnel plot asymmetry were significant, but publication bias seems unlikely here due to ceiling effects in both scores.

\section{Discussion}

In this study the functional outcomes and complications after surgical treatment of DMCF with an intramedullary device were systematically reviewed. Good functional results and union rates irrespective of the type of device are found in the reviewed literature. However, there are clear device-related and device-specific complications for each. The pooled Constant-Murley scores of the TEN and Sonoma CRx were 94.4 (95\%CI 93-95) and 94.0 (95\%CI 92-96), respectively. Since the Constant-Murley score ranges from 0 to 100 points and higher scores are better, the pooled scores can be considered good. Though the minimally clinical important difference (MCID) for both the Constant-Murley score is unknown for midshaft clavicular fractures in particular it is described that the MCID in Constant Murley scores for shoulder pathology is 10.4 points [81]. Therefore, with an SD reported well within that range our conclusion seems valid as is the confidence in the estimate according to GRADE. The pooled DASH score for the TEN 


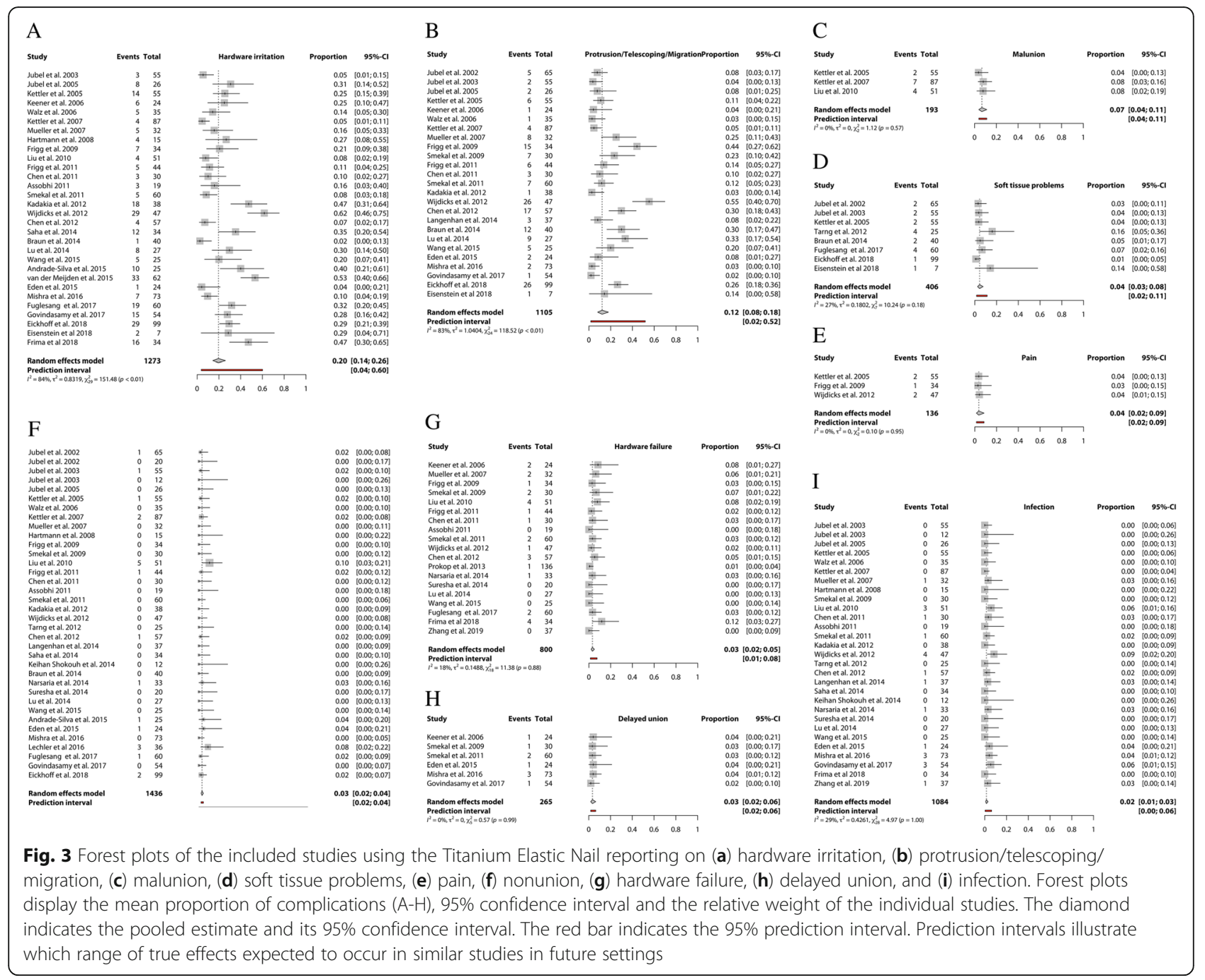

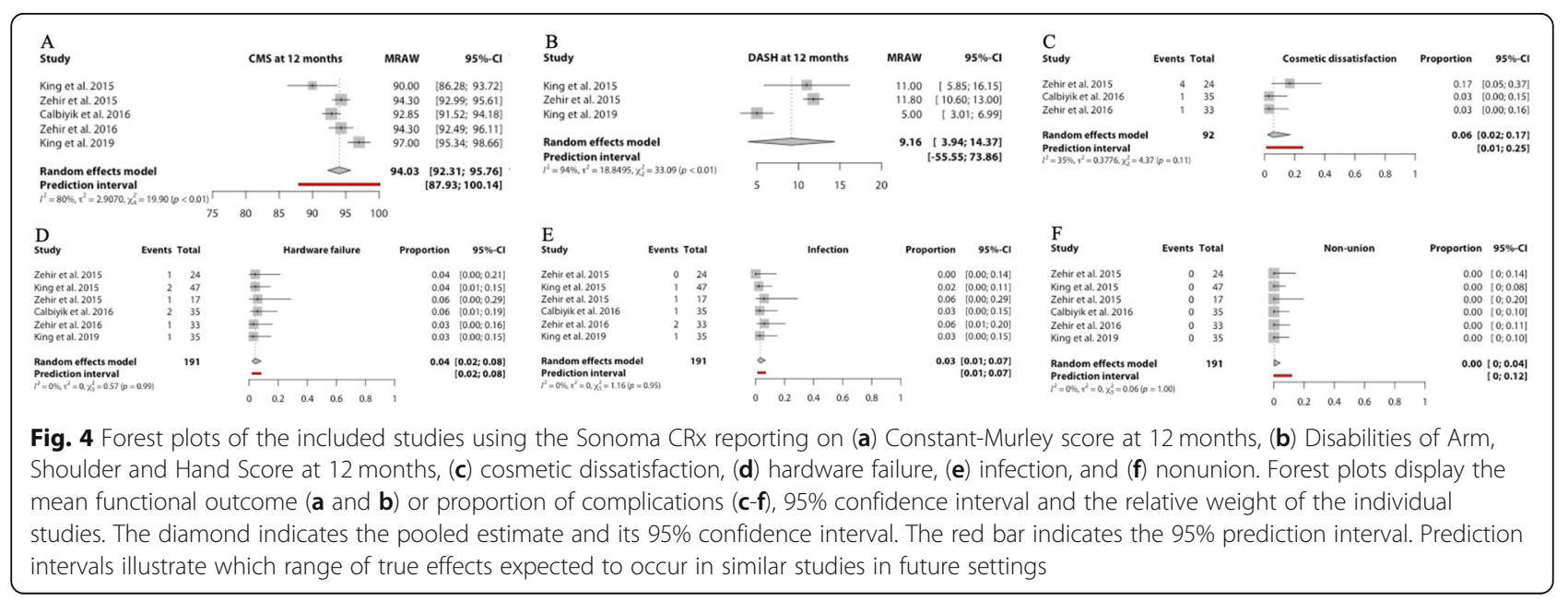


was 4.6 (95\%CI 2.6-6.7). The functional outcomes for the Rockwood/Hagie pin could not be analyzed because all identified papers reported different functional outcome measures. This study supports the need for uniform reporting of functional outcomes and in the case of clavicle fracture treatment the Constant-Murley and the DASH are the ones most commonly used.

The most commonly reported complications after intramedullary fixation of DMCFs are implant-related and implant-specific complications. For the TEN, hardware irritation, protrusion, telescoping and migration, are major contributors to the total complication rate. The explanation for this finding may be that the TEN re-aligns but does not fixate in both fracture elements of the DMCF. These TEN-specific complications lead to infection, soft-tissue problems, pain, early reinterventions (removal or additional cutting of the nail) and loss of reduction with subsequent secondary shortening. When using the Rockwood/Hagie Pin, pooled incidence of hardware irritation was $22 \%$ (95\%CI 13-35). This may be explained by the two bulky nuts at the posterolateral aspect of the clavicle where the pin is inserted and is has been reported to be an important disadvantage of the implant $[15,19,22]$. For the Sonoma CRx no reports on hardware irritation were found since this device has no extra-cortical prominences and is fully embedded in the clavicular cortex.

With regards to the TEN, there is a pooled malunion incidence of $7 \%$ (95\%CI 4-11). Reports on persistent average shortening after union range between 3.5 and $6.3 \mathrm{~mm}[27,37,54]$. Others report on shortening after union of more $>1 \mathrm{~cm}$ in $2.3-50 \%$ of cases $[41,57,60]$. Since shortening of the DMCF can lead to posttraumatic symptoms, altered scapular kinematics and the occurrence of gleno-humeral joint arthritis, shortening is an important issue to prevent and could be interpreted as a disadvantage of this intramedullary fixation device.

There are no studies specifically reporting on the presence or absence of post-operative shortening after fracture fixation with the Sonoma CRx. Concerning the Rockwood pin only Mudd et al. [21] reports a secondary shortening of 4-7 mm in $22 \%$ of patients which all occurred after early pin removal due to complications.

The pooled incidence for infection was $9 \%(95 \% \mathrm{CI}$ 5-16) when using the Rockwood/Hagie pin, 3\% (95\%CI 1-7) when using the Sonoma CRx and $2 \%$ (95\%CI 0-3) with use of the TEN. The two posterolateral nuts that can cause wound-breakdown and subsequent infection may explain the high infection rate of the Rockwood/Hagie pin.

Hardware failure was $6 \%(95 \% \mathrm{CI} 3-10)$ for the Rockwood/Hagie Pin compared to $3 \%(95 \%$ CI $2-5)$ for TEN and $4 \%(95 \% \mathrm{CI} 2-8)$.
Meta-analysis shows nonunion incidences to be similar between the Rockwood/Hagie pin $(3 \% ; 95 \%$ CI $1-8)$ and to $3 \%(95 \%$ CI $2-4)$ with the use of the TEN. The pooled incidence of nonunion for the Sonoma CRx was 0\% (95\%CI 0-4). Although no non-unions were reported in the Sonoma CRx group the confidence this outcome according to GRADE was low due to the limited number of clavicles included and the select group of authors introducing the risk of bias.

This systematic review furthermore identified the common denominator amongst many authors that routine removal of hardware is not considered a complication. However, a case could be made that every secondary intervention including hardware removal is an additional procedure which subjects the patient to associated morbidity and costs and therefore is not desirable.

As for all systematic reviews this study is limited by the quality of evidence available. In most meta-analyses of reported complications the evidence was graded as low to very low. Furthermore, only studies written in English, German or Dutch were included in this systematic review which could be a potential limitation of this study. Complications and early re-interventions are reported in some studies, [21, 33-35, 51, 54, 57] but underreporting is very likely to occur. Most studies do not clearly report causes for implant failure, measures taken with occurrence of infection or information concerning implant migration or secondary shortening. Only few specifically report on the presence or absence of certain relevant complications such as secondary shortening, neuropathy of the supraclavicular nerve, delayed union and persistent pain. This information could be interesting to fully report in future studies and is a limitation of this review. Another limitation is that not all functional outcomes and complications were reported in a similar manner leading to heterogeneity of the various studies. To account for the expected heterogeneity, a random effects model was used. In the case of functional outcome scores for TEN and Sonoma the confidence in the estimates was high and moderate, respectively. Lastly, the follow up differed between studies ranging from 3 months to 7 years. This may have resulted in differences in reporting of complications and functional outcomes. Although most complications would likely occur within the first 3 months this could lead to underreporting this could further negatively influence the confidence in the estimates reported.

In the last years multiple meta-analysis comparing the gold standard of plate fixation and intramedullary devices (irrespective of device or plate type) for the management of midshaft clavicle fractures have been published [82-89]. These studies report similar [82-84, 86-88] or superior [85, 89] functional outcomes and union rates in the intramedullary fixation group. 
Furthermore, most report a higher rate of complications (such as infection, refracture rate) and increased surgical time when using plate fixation, making an evaluation of the devices described in the present study even more relevant [82, 83, 86-89].

The results of this systematic review show there is still room for improvement in treating DMCF in an intramedullary fashion. For newer designs it may be interesting to take the implant-related and implant-specific complications described in this systematic review into account in order to optimize future treatment strategies.

\section{Conclusion}

Although most studies were of low quality, in general, good functional results and union rates irrespective of the type of device are found in the reviewed literature. However, there are clear device-related and devicespecific complications for each. The results of this systematic review and meta-analysis can help guide surgeons in choosing the appropriate operative strategy, implant and informing their patients.

\section{Supplementary information}

Supplementary information accompanies this paper at https://doi.org/10. 1186/s12891-020-03256-8.

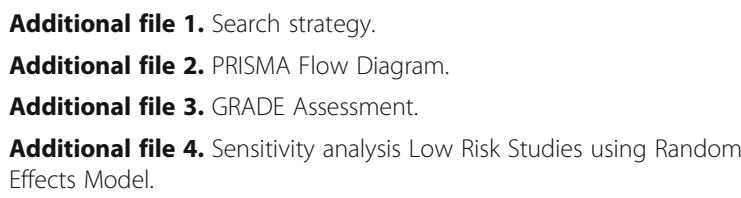

\section{Abbreviations}

ASES: American Shoulder Elbow Surgeons; Cl: Confidence interval; DASH: Disabilities of arm shoulder hand; DMCF: Displaced mid-shaft clavicle fractures; FL: Florida; IN: Indiana; LoE: Level of evidence; MCID: Minimally clinical important difference; MI: Michigan; ORIF: Open reduction internal fixation; PRISMA: Preferred reporting items for systematic reviews and metaanalyses; TEN: Titanium elastic nail; USA: United States of America

\section{Acknowledgements}

None.

\section{Authors' contributions}

$\mathrm{PH}$ contributed in the conception and design of the study, acquisition and analysis of the data, drafting and critical revision of the manuscript. TD contributed in the conception and design of the study, acquisition and analysis of the data, drafting and critical revision of the manuscript. NV contributed in the conception and design of the study and critical revision of the manuscript. $\mathrm{GH}$ contributed in the conception and design of the study, analysis of the data and critical revision of the manuscript. All authors read and approved the final version of the manuscript.

\section{Authors' information}

Paul Hoogervorst. Radboud University Medical Center, Nijmegen, The Netherlands. paul.hoogervorst@radboudumc.nl

Tess van Dam. BAAT Medical BV, Hengelo, the Netherlands.

Tess@baatmedical.com

Nico Verdonschot, Radboud University Medical Center, Nijmegen, The Netherlands.nico.verdonschot@radboudumc.nl

Gerjon Hannink. Radboud University Medical Center, Nijmegen, The Netherlands.gerjon.hannink@radboudumc.nl

\section{Funding}

Not applicable.

\section{Availability of data and materials}

The detailed search strategy for this systematic review is available in Additional file 2. The review protocol adhered to by the authors is available via PROSPERO (CRD42018086518). The PRISMA flowchart is available in Additional file 1. Additional file 3 and Additional file 4 contain the GRADE assessment by domain and the sensitivity analysis.

\section{Ethics approval and consent to participate}

The need for approval by the ethics committee and Consent to participate was waived by our institutional review board (CMO Arnhem-Nijmegen).

Consent for publication

Not applicable.

\section{Competing interests}

All authors declare that they have no competing interests.

\section{Author details}

'Department of Orthopedic Surgery, Radboud University Medical Center, P.O. Box 9101, 6500 HB Nijmegen, The Netherlands. ${ }^{2}$ Department of Orthopedic Surgery, University of Minnesota, 2450 Riverside Avenue South, Suite R200, Minneapolis, MN 55454, USA. ${ }^{3}$ BAAT Medical BV, Hengelo, The Netherlands. ${ }^{4}$ Department of Biomechanical Engineering, University of Twente, Enschede, The Netherlands. ${ }^{5}$ Department of Operating Rooms, Radboud University Medical Center Nijmegen, Enschede, The Netherlands.

Received: 1 August 2019 Accepted: 31 March 2020

Published online: 22 June 2020

\section{References}

1. Huttunen $\Pi$, Launonen AP, Berg HE, Lepola V, Fellander-Tsai L, Mattila VM. Trends in the incidence of clavicle fractures and surgical repair in Sweden: 2001-2012. J Bone Joint Surg Am. 2016;98:1837-42.

2. Kong $L$, Zhang $Y$, Shen $Y$. Operative versus nonoperative treatment for displaced midshaft clavicular fractures: a meta-analysis of randomized clinical trials. Arch Orthop Trauma Surg. 2014;134:1493-500.

3. McKee RC, Whelan DB, Schemitsch EH, McKee MD. Operative versus nonoperative care of displaced midshaft clavicular fractures: a meta-analysis of randomized clinical trials. J Bone Joint Surg Am. 2012;94:675-84.

4. Woltz S, Krijnen P, Schipper IB. Plate fixation versus nonoperative treatment for displaced Midshaft Clavicular fractures: a meta-analysis of randomized controlled trials. J Bone Joint Surg Am. 2017;99:1051-7.

5. Wijdicks FJ, Houwert M, Dijkgraaf M, de Lange D, Oosterhuis K, Clevers G, Verleisdonk EJ. Complications after plate fixation and elastic stable intramedullary nailing of dislocated midshaft clavicle fractures: a retrospective comparison. Int Orthop. 2012;36:2139-45.

6. Wijdicks FJ, Van der Meijden OA, Millett PJ, Verleisdonk EJ, Houwert RM. Systematic review of the complications of plate fixation of clavicle fractures. Arch Orthop Trauma Surg. 2012;132:617-25.

7. Moher D, Liberati A, Tetzlaff J, Altman DG, Group P. Preferred reporting items for systematic reviews and meta-analyses: the PRISMA statement. BMJ. 2009:339:b2535.

8. Higgins JP, Altman DG, Gotzsche PC, Juni P, Moher D, Oxman AD, Savovic J, Schulz KF, Weeks L, Sterne JA, et al. The Cochrane Collaboration's tool for assessing risk of bias in randomised trials. BMJ. 2011;343:d5928.

9. Sterne JA, Hernan MA, Reeves BC, Savovic J, Berkman ND, Viswanathan M, Henry D, Altman DG, Ansari MT, Boutron I, et al. ROBINS-l: a tool for assessing risk of bias in non-randomised studies of interventions. BMJ. 2016: 355:14919.

10. Simmonds M. Quantifying the risk of error when interpreting funnel plots. Syst Rev. 2015:4:24.

11. Egger M, Davey Smith G, Schneider M, Minder C. Bias in meta-analysis detected by a simple, graphical test. BMJ. 1997;315:629-34.

12. Peters JL, Sutton AJ, Jones DR, Abrams KR, Rushton L. Comparison of two methods to detect publication bias in meta-analysis. JAMA 2006;295:676-80. 
13. Atkins D, Best D, Briss PA, Eccles M, Falck-Ytter Y, Flottorp S, Guyatt GH, Harbour RT, Haugh MC, Henry D, et al. Grading quality of evidence and strength of recommendations. BMJ. 2004;328:1490.

14. IntHout J, loannidis JP, Rovers MM, Goeman JJ. Plea for routinely presenting prediction intervals in meta-analysis. BMJ Open. 2016;6:e010247.

15. Ferran NA, Hodgson P, Vannet N, Williams R, Evans RO. Locked intramedullary fixation vs plating for displaced and shortened mid-shaft clavicle fractures: a randomized clinical trial. J Shoulder Elb Surg. 2010;19:783-9.

16. Judd DB, Pallis MP, Smith E, Bottoni CR. Acute operative stabilization versus nonoperative management of clavicle fractures. Am J Orthop (Belle Mead NJ). 2009;38:341-5.

17. Kleweno CP, Jawa A, Wells JH, O'Brien TG, Higgins LD, Harris MB, Warner JJ. Midshaft clavicular fractures: comparison of intramedullary pin and plate fixation. J Shoulder Elb Surg. 2011;20:1114-7.

18. Wenninger JJ Jr, Dannenbaum JH, Branstetter JG, Arrington ED. Comparison of complication rates of intramedullary pin fixation versus plating of midshaft clavicle fractures in an active duty military population. J Surg Orthop Adv. 2013;22:77-81

19. Marlow WJ, Ralte P, Morapudi SP, Bassi R, Fischer J, Waseem M. Intramedullary fixation of diaphyseal clavicle fractures using the Rockwood clavicle pin: review of 86 cases. Open Orthop J. 2012;6:482-7.

20. Millett PJ, Hurst JM, Horan MP, Hawkins RJ. Complications of clavicle fractures treated with intramedullary fixation. J Shoulder Elb Surg. 2011;20:86-91.

21. Mudd CD, Quigley KJ, Gross LB. Excessive complications of open intramedullary nailing of midshaft clavicle fractures with the Rockwood clavicle pin. Clin Orthop Relat Res. 2011;469:3364-70.

22. Payne DE, Wray WH, Ruch DS, Zura RD, Moorman CT. Outcome of intramedullary fixation of clavicular fractures. Am J Orthop (Belle Mead NJ). 2011;40:E99-104.

23. Strauss EJ, Egol KA, France MA, Koval KJ, Zuckerman JD. Complications of intramedullary Hagie pin fixation for acute midshaft clavicle fractures. J Shoulder Elb Surg. 2007:16:280-4

24. Frye BM, Rye S, McDonough EB, Bal GK. Operative treatment of adolescent clavicle fractures with an intramedullary clavicle pin. J Pediatr Orthop. 2012;32:334-9.

25. Andrade-Silva FB, Kojima KE, Joeris A, Silva JS, Mattar R. Single, superiorly placed reconstruction plate compared with flexible intramedullary nailing for midshaft clavicular fractures: a prospective, randomized controlled trial. J Bone Joint Surg Am. 2015:97:620-6.

26. Assobhi JE. Reconstruction plate versus minimal invasive retrograde titanium elastic nail fixation for displaced midclavicular fractures. J Orthop Traumatol. 2011;12:185-92.

27. Chen QY, Kou DQ, Cheng XJ, Zhang W, Wang W, Lin ZQ, Cheng SW, Shen Y, Ying XZ, Peng L, Lv CZ. Intramedullary nailing of clavicular midshaft fractures in adults using titanium elastic nail. Chin J Traumatol. 2011;14:269-76.

28. Fuglesang HFS, Flugsrud GB, Randsborg PH, Oord P, Benth J, Utvåg SE. Plate fixation versus intramedullary nailing of completely displaced midshaft fractures of the clavicle. Bone Joint J. 2017;99B:1095-101.

29. Smekal V, Irenberger A, Attal RE, Oberladstaetter J, Krappinger D, Kralinger F. Elastic stable intramedullary nailing is best for mid-shaft clavicular fractures without comminution: results in 60 patients. Injury. 2011;42:324-9.

30. Smekal V, Irenberger A, Struve P, Wambacher M, Krappinger D, Kralinger FS. Elastic stable intramedullary nailing versus nonoperative treatment of displaced midshaft clavicular fractures-a randomized, controlled, clinical trial. J Orthop Trauma. 2009;23:106-12.

31. van der Meijden OA, Houwert RM, Hulsmans M, Wijdicks FJ, Dijkgraaf MG, Meylaerts SA, Hammacher ER, Verhofstad MH, Verleisdonk EJ. Operative treatment of dislocated midshaft clavicular fractures: plate or intramedullary nail fixation? A randomized controlled trial. J Bone Joint Surg Am. 2015;97:613-9.

32. Eden L, Ziegler D, Gilbert F, Fehske K, Fenwick A, Meffert RH. Significant pain reduction and improved functional outcome after surgery for displaced midshaft clavicular fractures. J Orthop Surg Res. 2015;10:190

33. Jubel A, Andermahr J, Bergmann H, Prokop A, Rehm KE. Elastic stable intramedullary nailing of midclavicular fractures in athletes. $\mathrm{Br} J$ Sports Med. 2003;37:480-3

34. Jubel A, Andermahr J, Prokop A, Lee JI, Schiffer G, Rehm KE. Treatment of midclavicular fractures in adults. Early results after rucksack bandage or elastic stable intramedullary nailing. Unfallchirurg. 2005;108:707-14.

35. Jubel A, Andermahr J, Schiffer G, Rehm KE. Technique of intramedullary osteosynthesis of the clavicle with elastic titanium nails. Unfallchirurg. 2002: 105:511-6.
36. Narsaria N, Singh AK, Arun GR, Seth RRS. Surgical fixation of displaced midshaft clavicle fractures: elastic intramedullary nailing versus precontoured plating. J Orthop Trauma. 2014;15:165-71.

37. Saha P, Datta P, Ayan S, Garg AK, Bandyopadhyay U, Kundu S. Plate versus titanium elastic nail in treatment of displaced midshaft clavicle fractures: a comparative study. Indian J Orthop. 2014:48:587-93.

38. Walz M, Kolbow B, Auerbach F. Elastic, stable intramedullary nailing in midclavicular fractures--a change in treatment strategies? Unfallchirurg. 2006;109:200-11.

39. Witzel K. Intramedullary osteosynthesis in fractures of the mid-third of the clavicle in sports traumatology. Z Orthop Unfall. 2007;145:639-42.

40. Chen Y-F, Wei H-F, Zhang C, Zeng B-F, Zhang C-Q, Xue J-F, Xie X-T, Lu Y. Retrospective comparison of titanium elastic nail (TEN) and reconstruction plate repair of displaced midshaft clavicular fractures. J Shoulder and Elbow Surg. 2012:21:495-501.

41. Jubel A, Andermahr J, Faymonville C, Binnebösel M, Prokop A, Rehm KE. Reconstruction of shoulder-girdle symmetry after midclavicular fractures. Stable, elastic intramedullary pinning versus rucksack bandage. Der Chirurg Zeitschrift für alle Gebiete der operativen Medizen. 2002;73:978-81.

42. Jubel A, Andermahr J, Schiffer G, Tsironis K, Rehm KE. Elastic stable intramedullary nailing of midclavicular fractures with a titanium nail. Clin Orthop Relat Res. 2003;408:279-85.

43. Lechler P, Sturm S, Boese CK, Bockmann B, Schwarting T, Ruchholtz S, Lahner M, Frink M. Surgical complications following ESIN for clavicular midshaft fractures do not limit functional or patient-perceived outcome. Injury. 2016:47:899-903.

44. Liu HH, Chang CH, Chia WT, Chen CH, Tarng YW, Wong CY. Comparison of plates versus intramedullary nails for fixation of displaced midshaft clavicular fractures. J Trauma. 2010;69:E82-7.

45. Mishra PK, Gupta A, Gaur SC. Midshaft clavicular fracture and titanium elastic intra-medullary nail. J Clin Diagn Res. 2014;8:129-32.

46. Tarng YW, Yang SW, Fang YP, Hsu CJ. Surgical management of uncomplicated midshaft clavicle fractures: a comparison between titanium elastic nails and small reconstruction plates. J Shoulder Elb Surg. 2012;21:732-40.

47. Wang YC, Fu YC, Chou SH, Liu PC, Tien YC, Lu CC. Titanium elastic nail versus plate fixation of displaced midshaft clavicle fractures: a retrospective comparison study. Kaohsiung J Med Sci. 2015;31:473-9.

48. Eickhoff A, Fischer M, Gebhard F, Ehrnthaller C. Complications after intramedullary stabilization of clavicle fractures. [German]. Unfallchirurg. 2018;121:810-6.

49. Frigg A, Rillmann P, Ryf C, Glaab R, Reissner L. Can complications of titanium elastic nailing with end cap for clavicular fractures be reduced? Clin Orthop Relat Res. 2011;469:3356-63.

50. Zhang T, Mei Y. Therapeutic effect analysis of closed reduction and intramedullary nail fixation for treatment of middle clavicular fracture. Int J Clin Exp Med. 2019:12:11603-10.

51. Braun KF, Siebenlist S, Sandmann GH, Martetschläger F, Kraus T, Schrödl C, Kirchhoff C, Neumaier M. Functional results following titanium elastic-stable intramedullary nailing (ESIN) of mid-shaft clavicle fractures. Acta Chir Orth Traum Cech. 2014:81:118-21.

52. Frigg A, Rillmann P, Perren T, Gerber M, Ryf C. Intramedullary nailing of clavicular midshaft fractures with the titanium elastic nail: problems and complications. Am J Sports Med. 2009;37:352-9.

53. Govindasamy R, Kasirajan S, Meleppuram JJ, Thonikadavath F. A retrospective study of titanium elastic stable intramedullary nailing in displaced mid-shaft clavicle fractures. Rev Bras Ortop. 2017;52:270-7.

54. Hartmann F, Hessmann MH, Gercek E, Rommens PM. Elastic intramedullary nailing of midclavicular fractures. Acta Chir Belg. 2008;108:428-32.

55. Kadakia AP, Rambani R, Qamar F, McCoy S, Koch L, Venkateswaran B. Titanium elastic stable intramedullary nailing of displaced midshaft clavicle fractures: a review of 38 cases. Int J Shoulder Surg. 2012;6:82-5.

56. Keihan Shokouh H, Naderi MN, Keihan Shokouh M. Treatment of midshaft clavicular fractures with elastic titanium nails. Trauma Mon. 2014;19:e15623

57. Kettler M, Schieker M, Braunstein V, Konig M, Mutschler W. Flexible intramedullary nailing for stabilization of displaced midshaft clavicle fractures: technique and results in 87 patients. Acta Orthop. 2007;78:424-9.

58. Kettler M, Schieker M, Braunstein V, König M, Mutschler W. Elastic stable intramedullary nailing (ESIN) of displaced midclavicular fractures with titanium nails. Aktuelle Traumatologie. 2005;35:303-7. 
59. Langenhan R, Reimers N, Probst A. Intramedullary stabilisation of displaced midshaft clavicular fractures: does the fracture pattern (simple vs. complex) influence the anatomic and functional result. Z Orthop Unfall. 2014;152:588-95.

60. Lu CC, Liu PC, Huang SH, Hsieh CH, Tien YC, Chien SH. Complications and technical pitfalls of titanium elastic nail fixation for midclavicular fractures. Orthopedics. 2014;37:e377-83.

61. Mueller M, Burger C, Florczyk A, Striepens N, Rangger C. Elastic stable intramedullary nailing of midclavicular fractures in adults: 32 patients followed for 1-5 years. Acta Orthop. 2007;78:421-3.

62. Suresha B, Srivastav S, Sud A, Singh H, Agarwal S. Titanium elastic nail fixation for clavicular fractures in adults. J Arthrosc Joint Surg. 2014;1:40-4.

63. Eisenstein ED, Misenhimer JJ, Kotb A, Thabet AM, Abdelgawad AA. Management of displaced midshaft clavicle fractures in adolescent patients using intramedullary flexible nails: a case series. J Clin Orthop Trauma. 2018; 9:S97-s102.

64. Frima H, Hulsmans MHJ, Houwert RM, Ahmed Ali U, Verleisdonk E, Sommer C, van Heijl M. End cap versus no end cap in intramedullary nailing for displaced midshaft clavicle fractures: influence on implant-related irritation. Eur J Trauma Emerg Surg. 2018;44:119-24.

65. Keener JD, Dahners LE. Percutaneous pinning of displaced midshaft clavicle fractures. Tech Shoulder Elbow Surg. 2006;7:175-81.

66. Prokop A, Schiffer G, Jubel A, Chmielnicki M. Intramedullary stabilisation of clavicula fractures. Z Orthop Unfall. 2013;151:449-51.

67. Calbiyik M, Zehir S, Ipek D. Minimally invasive implantation of a novel flexible intramedullary nail in patients with displaced midshaft clavicle fractures. Eur J Trauma Emerg Surg. 2016;42:711-7.

68. Zehir S, Zehir R, Sahin E, Calbiyik M. Comparison of novel intramedullary nailing with mini-invasive plating in surgical fixation of displaced midshaft clavicle fractures. Arch Orthop Trauma Surg. 2015;135:339-44.

69. King PR, Ikram A, Eken MM, Lamberts RP. The effectiveness of a flexible locked intramedullary nail and an anatomically contoured locked plate to treat Clavicular shaft fractures: a 1-year randomized control trial. J Bone Joint Surg Am. 2019;101:628-34.

70. King PR, Ikram A, Lamberts RP. The treatment of clavicular shaft fractures with an innovative locked intramedullary device. J Shoulder Elb Surg. 2015;24:e1-6.

71. Zehir S, Calbiyik M, Sahin E, Ipek D. Comparison between locked intramedullary nailing and anatomical locking plating in the treatment of displaced clavicular midshaft fractures. Acta Orthop Traumatol Turc. 2016;50: 291-7.

72. Zehir S, Akgul T, Zehir R. Results of midshaft clavicle fractures treated with expandable, elastic and locking intramedullary nails. Acta Orthop Traumatol Turc. 2015;49:13-7.

73. Bi H, Wang Y, Xiong Q, Li Y, Zhao Z, Yang Z. Minimally invasive fixation of midclavicular fractures with threaded elastic intramedullary nails. Eur J Orthop Surg Traumatol. 2015;25:833-40.

74. Grassi FA, Tajana MS, D'Angelo F. Management of midclavicular fractures: comparison between nonoperative treatment and open intramedullary fixation in 80 patients. J Trauma. 2001;50:1096-100.

75. Zenni EJ Jr, Krieg JK, Rosen MJ. Open reduction and internal fixation of clavicular fractures. J Bone Joint Surg Am. 1981;63:147-51.

76. Chu CM, Wang SJ, Lin LC. Fixation of mid-third clavicular fractures with knowles pins: 78 patients followed for 2-7 years. Acta Orthop Scand. 2002; 73:134-9.

77. Lee YS, Huang HL, Lo TY, Hsieh YF, Huang CR. Surgical treatment of midclavicular fractures: a prospective comparison of Knowles pinning and plate fixation. Int Orthop. 2008;32:541-5.

78. Lee YS, Lin CC, Huang CR, Chen GN, Liao WY. Operative treatment of midclavicular fractures in 62 elderly patients: Knowles pin versus plate. Orthopedics. 2007;30:959-64.

79. Wu CL, Chang HC, Lu KH. Risk factors for nonunion in 337 displaced midshaft clavicular fractures treated with Knowles pin fixation. Arch Orthop Trauma Surg. 2013;133:15-22.

80. Fu B. Minimally invasive intramedullary nailing of clavicular fractures by a new titanium elastic nail. Acta Orthop Traumatol Turc. 2016;50:494-500.

81. Wylie JD, Beckmann JT, Granger E, Tashjian RZ. Functional outcomes assessment in shoulder surgery. World J Orthop. 2014;5:623-33.

82. Houwert RM, Smeeing DP, Ahmed Ali U, Hietbrink F, Kruyt MC, van der Meijden OA. Plate fixation or intramedullary fixation for midshaft clavicle fractures: a systematic review and meta-analysis of randomized controlled trials and observational studies. J Shoulder Elb Surg. 2016;25:1195-203.
83. Hussain N, Sermer C, Prusick PJ, Banfield L, Atrey A, Bhandari M. Intramedullary nailing versus plate fixation for the treatment displaced Midshaft Clavicular fractures: a systematic review and meta-analysis. Sci Rep. 2016:6:34912.

84. Wang XH, Cheng L, Guo WJ, Li AB, Cheng GJ, Lei T, Zhao YM. Plate versus intramedullary fixation Care of Displaced Midshaft Clavicular Fractures: a meta-analysis of prospective randomized controlled trials. Medicine (Baltimore). 2015;94:e1792.

85. Xiao H, Gao H, Zheng T, Zhao J, Tian Y. Plate fixation versus intramedullary fixation for midshaft clavicle fractures: meta-analysis of complications and functional outcomes. J Int Med Res. 2016:44:201-15.

86. Xie L, Zhao Z, Zhang S, Hu Y. Intramedullary fixation versus plate fixation for displaced mid-shaft clavicle fractures: a systematic review of overlapping meta-analyses. Medicine (Baltimore). 2018;97:e9752.

87. Xu B, Lin Y, Wang Z, Cao J, Yang Y, Xia H, Zhang Y. Is intramedullary fixation of displaced midshaft clavicle fracture superior to plate fixation? Evidence from a systematic review of discordant meta-analyses. Int J Surg. 2017;43: 155-62.

88. Zhang B, Zhu Y, Zhang F, Chen W, Tian Y, Zhang Y. Meta-analysis of plate fixation versus intramedullary fixation for the treatment of mid-shaft clavicle fractures. Scand J Trauma Resusc Emerg Med. 2015;23:27.

89. Zhu Y, Tian Y, Dong T, Chen W, Zhang F, Zhang Y. Management of the mid-shaft clavicle fractures using plate fixation versus intramedullary fixation: an updated meta-analysis. Int Orthop. 2015;39:319-28.

\section{Publisher's Note}

Springer Nature remains neutral with regard to jurisdictional claims in published maps and institutional affiliations.
Ready to submit your research? Choose BMC and benefit from:

- fast, convenient online submission

- thorough peer review by experienced researchers in your field

- rapid publication on acceptance

- support for research data, including large and complex data types

- gold Open Access which fosters wider collaboration and increased citations

- maximum visibility for your research: over $100 \mathrm{M}$ website views per year

At $\mathrm{BMC}$, research is always in progress.

Learn more biomedcentral.com/submissions 